\title{
端部回転を受ける免震用積層ゴムの弾性理論 \\ AN ELASTIC THEORY ON LAMINATED RUBBER BEARINGS SUBJECTED TO END ROTATIONS
}

\author{
飯 塚真巨*，濱本卓司** \\ Masao IIZUKA and Takuji HAMAMOTO
}

\begin{abstract}
The end faces of laminated rubber bearings are subjected to large rotation in cases where the beams to which the bearings are attached are low in stiffness or are omitted. Since there have been few studies on the effect of end rotations on the mechanical properties of bearings, many points remain unclear. In this study, based on the Haringx theory, exact load-deflection relations are derived considering end rotations. Then, simplified expressions are derived as a first approximation, which make it easy to understand the effect of end rotations on the mechanical properties of bearings. To show another advantage of these approximate expressions, a bearing rotationally constrained by a superstructure is analyzed. It is shown that the solutions can be easily and accurately obtained by using these expressions. In addition, applicable deformation limits of these expressions obtained by elastic theory are presented. Based on numerical studies, effectiveness and accuracy of the above expressions are presented.
\end{abstract}

Keywords : base isolation system, laminated rubber bearing, mechanical theory, mechanical model, stiffness, buckling 免震、積層ゴム、力学理論、力学モデル、剛性、座屈

\section{1.はじめに}

積層ゴムを用いた免震構造の設計では、積層ゴムの水平剛性と座屈 荷重が最も重要な特性である。これらの特性に関する古典的力学理論 として、Haringx 理論 ${ }^{1)}$ がよく知られている。Gent ${ }^{2)}$ は Haringx 理論 を積層ゴムに適用し、積層ゴムの水平剛性および座屈荷重に関する理 論式を導いた。その理論はいくつかの文献犁え洁3) 5) に紹介され、理 論式は現在の積層ゴムの設計に広く活用されている。これらの文献に 紹介されている理論式は、積層ゴム端面に回転が生じないことを前提 に導出されている。一般には積層ゴムは剛強な梁で挟み込んで設置さ れるので、端面の回転は非常に小さく、理論式の前提条件は満足され ている。

ところで、免震レトロフィットでは積層ゴムを柱頭・柱脚などに設 置する例が多く見られる。また、最近では杭頭に免震装置を設置し、 杭頭間を軽微な基礎梁で連結する構法が検討・一部実施されている。 そのような場合の多くは、積層ゴムが取り付く上梁あるいは下梁が無 いか、もしくは軽微なため、剛強な梁がある一般の場合に比べて、積 層ゴム端面は大きな回転を受けることになる。このような場合、既往 理論式の前提条件は満足されないため、既往式をそのままの形で適用 すると大きな誤差を生じることになる。これまで、端部回転を受ける
積層ゴムの力学挙動に関する研究はほとんど行われておらず、端部回 転が力学挙動に及ぼす影響については不明な点が多い。 そこで、端部回転を生じる積層ゴムの力学挙動を明らかにする第一 段階として、積層ゴムの弹性的特性を解析的に把握することを目的に、 以下の事項を実施する。

(1) Haringx 理論に基づいて、材端での水平自由度と回転自由度を考 慮した剛性方程式を定式化する。また、積層ゴムの高さ方向の变 位分布・断面力分布に及ぼす鉛直荷重と端部回転の影響を事例に よって明らかにする。

(2) (1)で誘導した剛性方程式は複雑である。そこで、理解の促進と実 用性の観点から剛性方程式の近似式を誘導する。また、近似式の 有効性と利用法の一例を示すために、連結部材で端部回転が拘束 された積層ゴムの特性を近似式を用いて解析し、連結部材一積層 ゴム系の水平剛性式を誘導する。さらに、近似式および連結部材 一積層ゴム系の水平剛性式の精度を事例によって検証する。

(3) (1), (2)で提示した結果は、材料の線形性の仮定に基づいているた め、荷重・変形に対する適用限界が存在する。本論では、積層 ゴムのせん断特性, 曲げ特性の線形限界条件を規定し、その限界 条件に対匛する材端水平変位・材端回転角について考察する。

\footnotetext{
本論文の一部は既に文献6)において発表されている。

* 鹿島建設技術研究所 上席研究員・修士(工学)

**武藏工業大学工学部建築学科 教授・工博
}

Supervisory Research Engineer, Kajima Technical Research Institute, Kajima Corp., M. Eng.

Prof., Dept. of Architecture, Faculty of Engineering, Musashi Institute of Technology, Dr. Eng. 


\section{Haringx 理論}

\section{1 理論の概要}

Haringx 理論の概念図を図 1 に示す。積層ゴムの両端 (A, B 端) に、 鉛直荷重 $P$ 、水平力 $Q_{A}, Q_{B}$ 、曲げモーメント $M_{A}, M_{B}$ が作用し、 水平变位 $\delta_{A}, \delta_{B}$ 、回転角 $\theta_{A}, \theta_{B}$ が生じている状態を考える。この とき積層ゴムの内部では、任意高さ $z$ 位置で水平変位 $x$ が生じ、高 さ $z$ における平面 $\left(a-a^{\prime}\right.$ 面) は、回転角 $\theta$ で回転し、せん断変形角 $\gamma_{s}$ が生じている。また $a-a^{\prime}$ 面には断面力として曲げモーメント $M$ お よび回転面に沿うせん断力 $Q_{s}$ が生じている。座標系および荷重・断 面力と変位・変形の正方向は図 1 のとおりである。鉛直荷重は圧縮を 正とする。定式化に際し、鉛直方向の変位を無視し、回転角は微小て あるとする。また、材料は線形であると仮定する。

Haringx 理論では、P- $\mathrm{P}$ 効果による付加曲げモーメントを考虑し ている点、および曲げで傾斜した面に沿う鉛直荷重の分力が付加せん 断力として作用し、せん断変形を增大させる効果（以下、この効果の ことを、曲げの「 $\mathrm{P}-\Delta$ 効果」に対応させて「 $\mathrm{P}-\boldsymbol{\theta}$ 効果」と呼ぶこと にする）を考虑している点の二点が特徽である。

\section{2 㓮性方程式の筫出}

$\mathrm{P}-\Theta$ 効果および $\mathrm{P}-\Delta$ 効果は以下の二つの力のつり合い式(1)，(2) 式の中で考虑される。すなわち、 $a-a^{\prime}$ 面でのせん断力のつり合いお よび $a-a^{\prime}$ 面での曲げモーメントのつり合いは下式である。

$$
\begin{aligned}
& Q_{s}=-Q_{B}+P \theta \\
& M=M_{B}-Q_{B} z+P\left(x-\delta_{B}\right)
\end{aligned}
$$

軸心の傾斜角は下式で与えられる。

$$
\frac{d x}{d z}=\gamma_{s}+\theta
$$

せん断力とせん断変形角の関保および曲げモーメントと曲率の関俰

は、 $S_{s}, S_{b}$ をせん断剛性，曲げ剛性として次の関係にある。

$$
\begin{aligned}
& Q_{s}=S_{s} \gamma_{s} \\
& M=-S_{b} \frac{d \theta}{d z}
\end{aligned}
$$

$S_{s}, S_{b}$ は中間鋼板を剛として、下式で与えられる ${ }^{3) \sim 5) 。 ~}$

$$
\begin{aligned}
S_{s} & =\frac{l}{h} G A \\
S_{b} & =\frac{l}{h} E_{b}^{\prime} I \\
\text { ここに、 } & \\
E_{b}^{\prime} & =\frac{1}{1 / E_{b}+1 / E_{\infty}} \\
E_{b} & =\left(1+\frac{2}{3} \kappa S_{1}^{2}\right) E \quad \text { (ただし、円形断面に対して) }
\end{aligned}
$$

ここで、Gはゴムのせん断弾性係数、 $E_{b}^{\prime}$ はゴムの圧縮性を考慮した 曲げに関する見かけの縦弹性俰数、 $E_{b}$ はゴムを非圧縮性とした曲け に関する見かけの縦弾性俰数、 $E_{\infty}$ はゴムの体積弾性係数、 $E$ はゴム

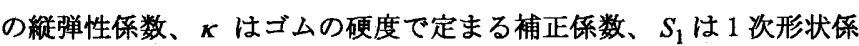
数（円形断面の場合、 $S_{1}=D /\left(4 t_{r}\right) ; D$ : 直径、 $t_{r}:$ ゴム 1 層厚)、 $A$ は断面積， $I$ は断面 2 次モーメント，lは積層ゴムの全高さ（イン サートプレートを含み、フランジプレートを除く)，hはゴム層の総 厚さである。

(1)〜 (5) 式から、つぎの微分方程式が誘導される。

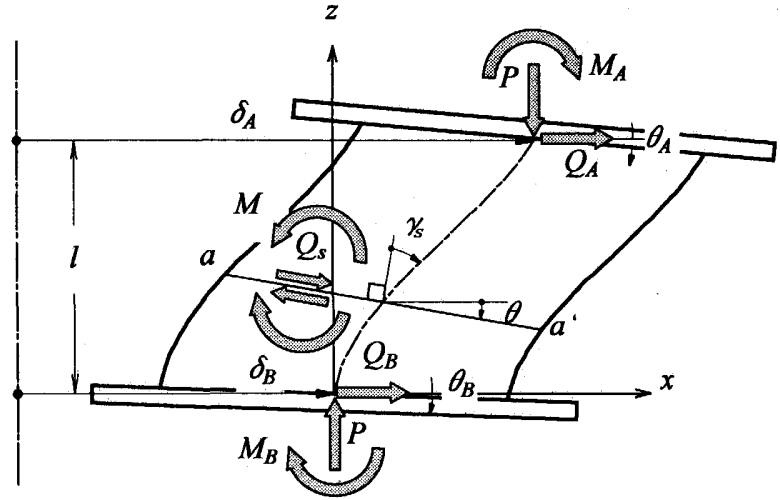

图 1 Haringx 理論の概念図

$$
\begin{aligned}
& \frac{d^{2} x}{d z^{2}}+q^{2} x-\frac{q^{2}}{P}\left(-M_{B}+Q_{B} z+P \delta_{B}\right)=0 \\
& \text { ここに、 } \\
& q^{2}=\frac{P}{S_{b}}\left(1+\frac{P}{S_{s}}\right)
\end{aligned}
$$

（10）式の一般解は積分定数 $C_{1} ， C_{2}$ を含む下式である。

$$
\begin{aligned}
& x=C_{1} \sin q z+C_{2} \cos q z+\frac{1}{P}\left(-M_{B}+Q_{B} z\right)+\delta_{B} \\
& \theta=\frac{1}{1+\frac{P}{S_{s}}}\left(C_{1} q \cos q z-C_{2} q \sin q z\right)+\frac{Q_{B}}{P}
\end{aligned}
$$

境界条件は以下のとおりである。

i) $z=0$ で $x=\delta_{B}$

ii) $z=0$ で $\theta=\theta_{B}$

iii) $z=l$ で $x=\delta_{A}$

iv) $z=l$ で $\theta=\theta_{A}$

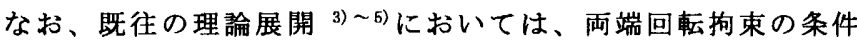
$\left(\theta_{A}=\theta_{B}=0\right)$ を仮定しているが、本論では $\theta_{A}, \theta_{B}$ を任意として扱つ ているところが異なっている。

端部に作用する外力は以下のつり合いを満足している。

$$
\begin{aligned}
& Q_{A}+Q_{B}=0 \\
& M_{A}+M_{B}-Q_{B} l+P\left(\delta_{A}-\delta_{B}\right)=0
\end{aligned}
$$

(12)，(13)式の一般解に上記境界条件と外力のつり合い式(14)，(15) 式を用いると、次の剛性方程式が得られる。

$$
\begin{aligned}
& \left\{\begin{array}{c}
Q_{A} \\
M_{A} \\
Q_{B} \\
M_{B}
\end{array}\right\}=\left[\begin{array}{cccc}
k_{1} & k_{2} & -k_{1} & k_{2} \\
& k_{3} & -k_{2} & k_{4} \\
& & k_{1} & -k_{2} \\
& s y m . & & k_{3}
\end{array}\right]\left\{\begin{array}{c}
\delta_{A} \\
\theta_{A} \\
\delta_{B} \\
\theta_{B}
\end{array}\right\} \\
& \text { ここに、 } \\
& k_{1}=k_{h} \\
& k_{2}=-k_{h} \frac{S_{b} q}{P} \tan \frac{q l}{2}=-\frac{1}{2}\left(l k_{h}+P\right) \\
& k_{3}=k_{h}\left(\frac{S_{b} q}{P} \tan \frac{q l}{2}\right)^{2}+\frac{S_{b} q}{\tan q l}=\frac{l}{4}\left(l k_{h}+P\right)+k_{r} \\
& k_{4}=k_{h}\left(\frac{S_{b} q}{P} \tan \frac{q l}{2}\right)^{2}-\frac{S_{b} q}{\sin q l}=\frac{l}{4}\left(l k_{h}+P\right)-k_{r}
\end{aligned}
$$$$
\text { ここに、 }
$$$$
k_{h}=\frac{P^{2}}{2 S_{b} q \tan \frac{q l}{2}-P l}
$$ 


$$
k_{r}=\frac{\frac{q l}{2}}{\tan \frac{q l}{2}} \frac{S_{b}}{l}
$$

$k_{h}$ は一端固定他端水平移動自由回転拘束の境界条件下での既往の 水平剛性式 3) 5) である。(17.b) (17.d) には二つの等式が示されて いる。一つ目の等式は、筆者 $\left.{ }^{6}\right)$ が定式化したものである。その後、三 山核物理的な意味をより明確化した二つ目の等式を導いた。

上式において、 $\tan (q l / 2), \sin q l, \tan q l$ をMaclaulin 展開し、 $P=0$ とすれば、(16)式はつぎの曲げせん断要素の剛性方程式に一致する。

$$
\left\{\begin{array}{l}
Q_{A} \\
M_{A} \\
Q_{B} \\
M_{B}
\end{array}\right\}=\frac{1}{\frac{l^{3}}{12 S_{b}}+\frac{l}{S_{s}}}\left[\begin{array}{cccc}
1 & -\frac{l}{2} & -1 & -\frac{l}{2} \\
\frac{l^{2}}{3}+\frac{S_{b}}{S_{s}} & \frac{l}{2} & \frac{l^{2}}{6}-\frac{S_{b}}{S_{s}} \\
& 1 & \frac{l}{2} \\
\text { sym. } & & \frac{l^{2}}{3}+\frac{S_{b}}{S_{s}}
\end{array}\right]\left\{\begin{array}{l}
\delta_{A} \\
\theta_{A} \\
\delta_{B} \\
\theta_{B}
\end{array}\right\}
$$

\section{3 変位分布と断面力分布}

高さ方向の変位分布および断面力分布を、以下のようにして求める ことができる。(16)〜 (19)式の剛性方程式を得る計算過程で、積分定 数が以下のように得られている。

$$
\begin{aligned}
& C_{1}=\frac{S_{b} q}{P}\left(\theta_{B}-\frac{Q_{B}}{P}\right) \\
& C_{2}=\frac{M_{B}}{P}
\end{aligned}
$$

想定している境界条件を(16)式に与え、すべての材端力・材端変位 を求めた後、それらの結果を上式に代入して $C_{1}, C_{2}$ を求め、 (12)，(13) 式加ら任意高さ $z$ における水平変位 $x$ と回転角 $\theta$ が求め られる。さらに(1)，(2)，(4)，(5)式からせん断力 $Q_{s}$, 曲げモーメン 卜 $M$ ，せん断変形角 $\gamma_{s}$, 曲率 $d \theta / d z$ が求められる。なお、 $\gamma_{s}$ と $d \theta / d z$ はゴム層と中間鋼板の複合体を等価な均質材料で置換した部 材に対するものである。 $\gamma_{s}$ と $d \theta / d z$ をゴム層の実質的な值に変換す るには、これらにl/hを乗じればよい。

\section{3. 刷性方程式の近似式}

\section{1 近似式の誘等}

(a) 纳定

（17）（19）式は難解であり、鉛直荷重や端部回転角の影響が直感的 に理解できない。そこで、建物免震用積層ゴムを想定して、近似式で 表す。

建物免震用積層ゴムでは、一般に次の条件が成立している。

$$
1 \ll \frac{P}{S_{s}}<\frac{P_{c r}}{S_{s}} \ll \frac{S_{b} / l^{2}}{S_{s}}
$$

ここで、 $P_{c r}$ は座屈荷重 (次節参照)である。ちなみに、後述の事例検 討用の皘層ゴムで (表 1 参照) 上の数值を求めると、 $\left(S_{b} / l^{2}\right) / S_{s}=598$ 、 $P_{c r} / S_{s}=77$ である。 $P$ に関しては、長期の設計鉛直荷重レベルを $P_{c r} / 4$ とすれは， $P / S_{s}=19$ である。一般によく使用されている積層 $\exists ゙ ム の ~\left(S_{b} / l^{2}\right) / S_{s}$ は、事例検討用の積層ゴムと同等であり、(23)式 の仮定は妥当である。

\section{（b）座届荷重}

一端固定他端水平移動自由回転拘束の境界条件下での水平剛性 $k_{h}$ をぜ口にする鉛直荷重を座屈荷重 $P_{c r}$ と定義する。(18) 式から、 $q l=\pi$ のとき $P=P_{c r}$ となるので、これらを(11) 式に代入して、 $P_{c r} に$ ついて解くと、下式が得られる。

$$
P_{c r}=\frac{S_{s}}{2}\left(\sqrt{1+4 \pi^{2} \frac{S_{b} / l^{2}}{S_{s}}}-1\right)
$$

上式に（23）式の条件 $\left(\left(S_{b} / l^{2}\right) / S_{s} \gg 1\right)$ を適用すると下式となる。

$$
P_{c r}=\frac{\pi}{l} \sqrt{S_{s} S_{b}}
$$

(24)，(25) 式は積層ゴムの座屈荷重として知られた式である ${ }^{3), ~ E) 。 ~}$

(c) 近似式

（17）式を難解にしている主な原因は $k_{h}$ と $k_{r}$ の式である。これらの 式は、下式で近似できることが知られている ${ }^{8), 5) 。 ~}$

$$
\begin{aligned}
& k_{h}=\left(1-p^{2}\right) \frac{S_{s}}{l} \\
& k_{r}=\left(1-p^{2}\right) \frac{S_{b}}{l} \\
\text { ここで、 } & p=P / P_{c r}
\end{aligned}
$$

(26)，(27)式を(17)式に代入して下式となる。

$$
\begin{aligned}
& k_{1}=\left(1-p^{2}\right) \frac{S_{s}}{l} \\
& k_{2}=-\frac{1}{2}\left\{\left(1-p^{2}\right) S_{s}+P\right\} \\
& k_{3}=\frac{l}{4}\left\{\left(1-p^{2}\right) S_{s}+P\right\}+\left(1-p^{2}\right) \frac{S_{b}}{l} \\
& k_{4}=\frac{l}{4}\left\{\left(1-p^{2}\right) S_{s}+P\right\}-\left(1-p^{2}\right) \frac{S_{b}}{l}
\end{aligned}
$$

三山 ${ }^{7)}$ は (29) 式に水平変形に依存した非線形性を表わすための保数 を導入した解析法を提案している。本論では、(29)式に（23）式の条件 を適用して、さらに简略化した下式を得る。

$$
\begin{aligned}
& k_{1}=\left(1-p^{2}\right) \frac{S_{s}}{l} \\
& k_{2}=-\frac{P}{2} \\
& k_{3}=\left(1-p^{2}\right) \frac{S_{b}}{l} \\
& k_{4}=-\left(1-p^{2}\right) \frac{S_{b}}{l}
\end{aligned}
$$

（30）式を用いて(16)式を書き直すと下式である。

$$
\begin{aligned}
& Q_{A}=-Q_{B}=\left(1-p^{2}\right) \frac{S_{s}}{l}\left(\delta_{A}-\delta_{B}\right)-\frac{P}{2}\left(\theta_{A}+\theta_{B}\right) \\
& M_{A}=-\frac{P}{2}\left(\delta_{A}-\delta_{B}\right)+\left(1-p^{2}\right) \frac{S_{b}}{l}\left(\theta_{A}-\theta_{B}\right) \\
& M_{B}=-\frac{P}{2}\left(\delta_{A}-\delta_{B}\right)-\left(1-p^{2}\right) \frac{S_{b}}{l}\left(\theta_{A}-\theta_{B}\right)
\end{aligned}
$$

(30)式は(17)～(19) 式に比べてはるかに简潔な式となっており、積 層ゴムの力学挙動に及ぼす鈆直荷重や端部回転角の影響が明確に表 現されている。ただし、水平力による曲げモーメントが無視されてい ることに注意する必要がある。

\section{（d）近似式の論理的解釈}

(26) 式は、Buckle 等 ${ }^{8)}$ が初めて提案したものであるが、誘導過程 と論理的根拻が明示されていない。その後の文献においても、論理的 
根拠について詳しく触れたものが見当たらない。（27)式についても 同様である。（31) 式の近似式を提案するに当たり、(26)，(27) 式に対 する論理的解釈を与えておくことは重要であると考え、以下に記述す る。

付録には、（18) 式に $1 \ll\left(S_{b} / l^{2}\right) / S_{s}$ および $1 \ll P_{c r} / S_{s}$ の条件を用 いて、下式の近似式が得られることが示されている。

$$
k_{h}=\left(1-\frac{\pi^{2}}{12} p^{2}\right) \frac{S_{s}}{l}
$$

なお、上式は下式で定義される新たな座屈荷重を用いて、(26)式と同 じ形に変形できる。

$$
P_{c r}=\frac{\sqrt{12}}{l} \sqrt{S_{s} S_{b}}
$$

(32) 式は、Maclaul in 展開の 2 次までの項を残した純数学的な近似式 である。従って、Pが小さい領域での精度は高いが、Pの增大とと もに精度が落ち、㓮性を過大に評価する。（33）式が理論式(25) 式と 異なるのは、級数展開の高次の項を無視したことに起因している。そ こで、（32）式で $\pi^{2} / 12=1$ とすれば、 $p=1$ すなわち $P=P_{c r}$ のときに $k_{h}=0$ となり、座屈に関する理論的な矛盾が解消できる。それが (26) 式である。すなわち、(25)式の $P_{c r}$ を用いた (26) 式は、純数学的な近 似に加えて、座屈荷重が理論值に合致するように物理的な意味から修 正したものと解釈できる。後述するように (5.3 節参照)、(26)式は （32）式よりも精度が良く、しかも設計上重要な特性值である座屈荷重 が理論值と一致する簡明さを備えている。(27)式についても上記と同 じ議論が当てはまる。

\section{2 近似式の応用例}

上で示した剛性方程式の近似式は、架構中に組み込まれた積層ゴム の力学特性の理論的な定式化に利用できる。以下、一例として図 2 に 示す簡単なモデルを用いてそれを示す。図 2 は、連結部材の回転剛性 を表す回転ばねによって積層ゴム端部の回転を拘束したモデルで、 Imbimbo 等 ${ }^{9}$ によって検討されたものである。簢単のため、積層ゴ 下端および回転ばね上端の回転を固定する。回転ばねのモーメントー 回転角関倸は下式である。

$$
M_{F}=K_{F} \theta_{F}=K_{F} \theta_{A}
$$

ここで、 $K_{F}$ は回転ばねの剛性、 $M_{F}, \theta_{F}$ は回転ばね下端のモーメン 卜と回転角、 $\theta_{A}$ は積層ゴム上端の回転角である。上式の二つ目の等 式は、変位の連続条件 $\theta_{F}=\theta_{A}$ による。また、モーメントのつり合い は下式である。

$$
M_{A}+M_{F}=0
$$

ここで、 $M_{A}$ は積層ゴム上端のモーメントである。(35)式に(31.b) 式(ただし、 $\left.\theta_{B}=0\right) ，(34)$ 式を代入して下式が得られる。

$$
\theta_{A}=\frac{1}{1+k_{F}-p^{2}} \frac{P}{2} \frac{l}{S_{b}}\left(\delta_{A}-\delta_{B}\right)
$$

ここで、

$$
k_{F}=\frac{K_{F}}{S_{b} / l}
$$

（36)式を(31.a) 式(ただし、 $\left.\theta_{B}=0\right)$ に代入し、（25) 式の関俰を用い て整理すると下式が得られる。

$$
Q_{A}=K_{h}\left(\delta_{A}-\delta_{B}\right)
$$

ここで、

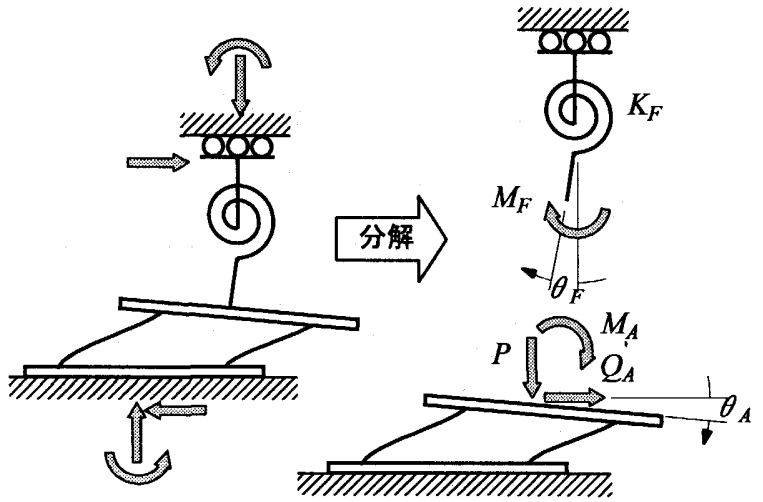

図 2 連軺部材の回転拘束を考虚した積層ゴムー連結部材モデル

$$
\frac{K_{h}}{S_{s} / l}=1-\frac{\pi^{2} / 4+1+k_{F}-p^{2}}{1+k_{F}-p^{2}} p^{2}
$$

上式を、Maclaulin 展開して 2 次までの項を採ると下式となる。

$$
\frac{K_{h}}{S_{s} / l}=1-\frac{\pi^{2} / 4+1+k_{F}}{1+k_{F}} p^{2}
$$

上式において、 $k_{F} \rightarrow \infty$ の場合、 $p^{2}$ の係数は 1 となるので、既往式 (26) 式に一致する。ところが、 $k_{F}=0$ (回転自由)の場合、 (40) 式を ぜロにする鉿直荷重は $0.537 P_{c r}$ となって、理論值である $0.5 P_{c r}$ を過大 に評価する。この誤差は級数展開の高次の項を無視したことに起因し ている。そこで、3.1 (d) で述べたと同様に、座屈荷重を理論值に一致 させるように、 $\pi^{2}=12$ とおけば、（40)式は下式となる。

$$
\frac{K_{h}}{S_{s} / l}=1-\frac{4+k_{F}}{1+k_{F}} p^{2}
$$

上式は、文献 [9]で最終的に得られた近似式である。ただし、文献 [9] では、（33）式で定義された $P_{c r}$ を用いており、（25)式ではない。しか

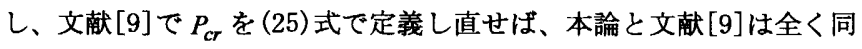
一の結論に至ることになる。

文献[9]では Haringx 理論の基礎式から展開を始め、更に各種の近 似計算を含む膨大な計算の末、(41) 式の結論に辿り着いている。一方 上の例から、(31) 式を利用すれは、極めて簡単な計算で同一の結果が 得られることが示された。より複雑なモデルを想定した場合、(31) 式 がさらに有効になるものと考えられる。

\section{Haringx 理論の適用可能な変形限界}

本理論は材料の線形性を仮定しているので、理論が適用可能な変形 限界を明示しておくことは重要である。

(4)式の成立条件を下式とする。

$$
\frac{l}{h}\left|\gamma_{s}(z)\right| \leq \gamma_{h}
$$

ここで、 $(l / h)\left|\gamma_{s}(z)\right|$ 注任意高さ $z$ におけるゴム層のせん断ひずみ度、 $\gamma_{h}$ は線形限界せん断ひずみ度（ハードニング開始時せん断ひずみ 度）である。なお、一般に $\gamma_{h}=2$ 程度であることが知られている。

一方、(5)式の成立条件を下式とする。

$|M(z)| \leq M_{y}$

ここで、 $M(z)$ は任意高さ $z$ における曲げモーメント、 $M_{y}$ は積層ゴ ムの線形限界曲げモーメントである。 $M_{y}$ を断面の縁応力度が降伏応 力度に達したときの曲げモーメント（降伏モーメント）として定義す

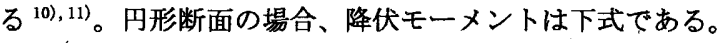


表 1 ケーススタディ用積層ゴムの形状・材料諸元

\begin{tabular}{|c|c|c|c|}
\hline 直径 & $\bar{D}$ & $(\mathrm{~mm})$ & 800 \\
\hline ゴム層 $\times$ 枚数 & $t_{r} \times n_{r}$ & $(\mathrm{~mm})$ & $5.0 \times 40$ \\
\hline ゴム層の総厚 & $h$ & $(\mathrm{~mm})$ & 200 \\
\hline 中間鋼板厚 & $t_{s}$ & $(\mathrm{~mm})$ & 4.0 \\
\hline 全高さ & $l$ & $(\mathrm{~mm})$ & 356 \\
\hline 1 次形状係数 & $S_{1}$ & & 40.0 \\
\hline 2 次形状係数 & $S_{2}$ & & 4.0 \\
\hline
\end{tabular}

\begin{tabular}{lcc|c}
\hline ゴムの維弾性係数 & $E$ & $\left(\mathrm{~N} / \mathrm{mm}^{2}\right)$ & 2.20 \\
\hline ゴムのせん断弾性係数 & $G$ & $\left(\mathrm{~N} / \mathrm{mm}^{2}\right)$ & 0.392 \\
\hline ゴムの体積弾性係数 & $E_{\infty}$ & $\left(\mathrm{N} / \mathrm{mm}^{2}\right)$ & 1180 \\
\hline ゴム硬度による補正係数 & $\kappa$ & & 0.85 \\
\hline ゴムの引張り降伏応力度 & $\sigma_{y}$ & $\left(\mathrm{~N} / \mathrm{mm}^{2}\right)$ & 1.47 \\
\hline 座屆応力度（注参照） & $\sigma_{c r}$ & $\left(\mathrm{~N} / \mathrm{mm}^{2}\right)$ & 53.2 \\
\hline
\end{tabular}

$$
M_{y}=Z\left(\sigma-\sigma_{y}\right)=\frac{D P}{8}\left(1-\frac{P_{y}}{P}\right)
$$

ここで、 $Z$ は断面保数、 $\sigma$ は平均垂直応力度、 $\sigma_{y}$ は引張り降伏応力度 $\left(\sigma_{y}<0\right) 、 P_{y}$ は引張 り降伏荷重 $\left(P_{y}<0\right) 、 D$ は直径である。

鈴木等 ${ }^{12)}$ はゴム 1 層の純曲げ試験から、曲げ モーメントー曲率関保が $M_{y}$ 程度まではほぼ線 形で、それを超えると剛性低下する結果を得て いる。（44）式の定義は、理想化した応力度分布 を仮定しており、ゴム層内の圧力分布を厳密に 反映させたものではない。しかしながら、文献 [12]の実験結果は、(44) 式が線形限界曲げモー メントとして適用できることを示晙している。

ここで、逆対称曲げ $\left(\theta_{A}-\theta_{B}=0\right)$ に対する線 形限界水平変形は基本的な量になるので、それ を以下に示しておく。 $S_{s} \ll P$ の場合、(31.b) 式あるいは (31.c) 式から、 $M_{A}=M_{B}$ $\approx-P\left(\delta_{A}-\delta_{B}\right) / 2$ であり、(43),(44) 式より下 式が得られる（ただし、 $-P_{y} / P \ll 1 ） 。$

$$
\left|\delta_{A}-\delta_{B}\right| \leq D / 4
$$

すなわち、逆対称曲げにおける線形限界水平 変形は概ね直径の $1 / 4$ であり、それ以下の水平 変形に対して Haringx 理論が適用可能である。

\section{5. 事例検討}

\section{1 検討用積層ゴムと検討項目}

表 1 に示す 2 次形状倸数 4 の低减衰積層ゴム を例として、以下の諸点を検討する。

1）端部回転が生じたときの積層ゴムの変位・ 断面力の分布状況

2）剛性マトリクスの要素の近似式 [(30) 式] の精度

3）連結部材の回転剛性を考慮した積層ゴムの 水平剛性式 [(40), (41) 式] の精度

4) 本論で提示した理論式が適用可能な変形限 界に与える端部回転の影響

\section{2 変位分布}

以下の二つの変形パターンについて計算した。

・一端固定他端回転無し

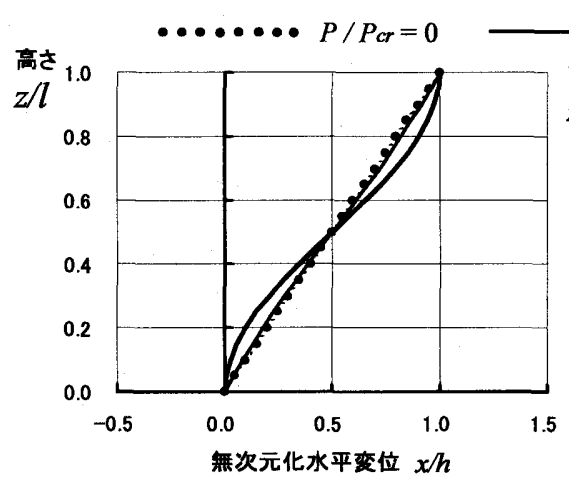

$P / P c r=0.5$

$P / P_{c r}=1.0$
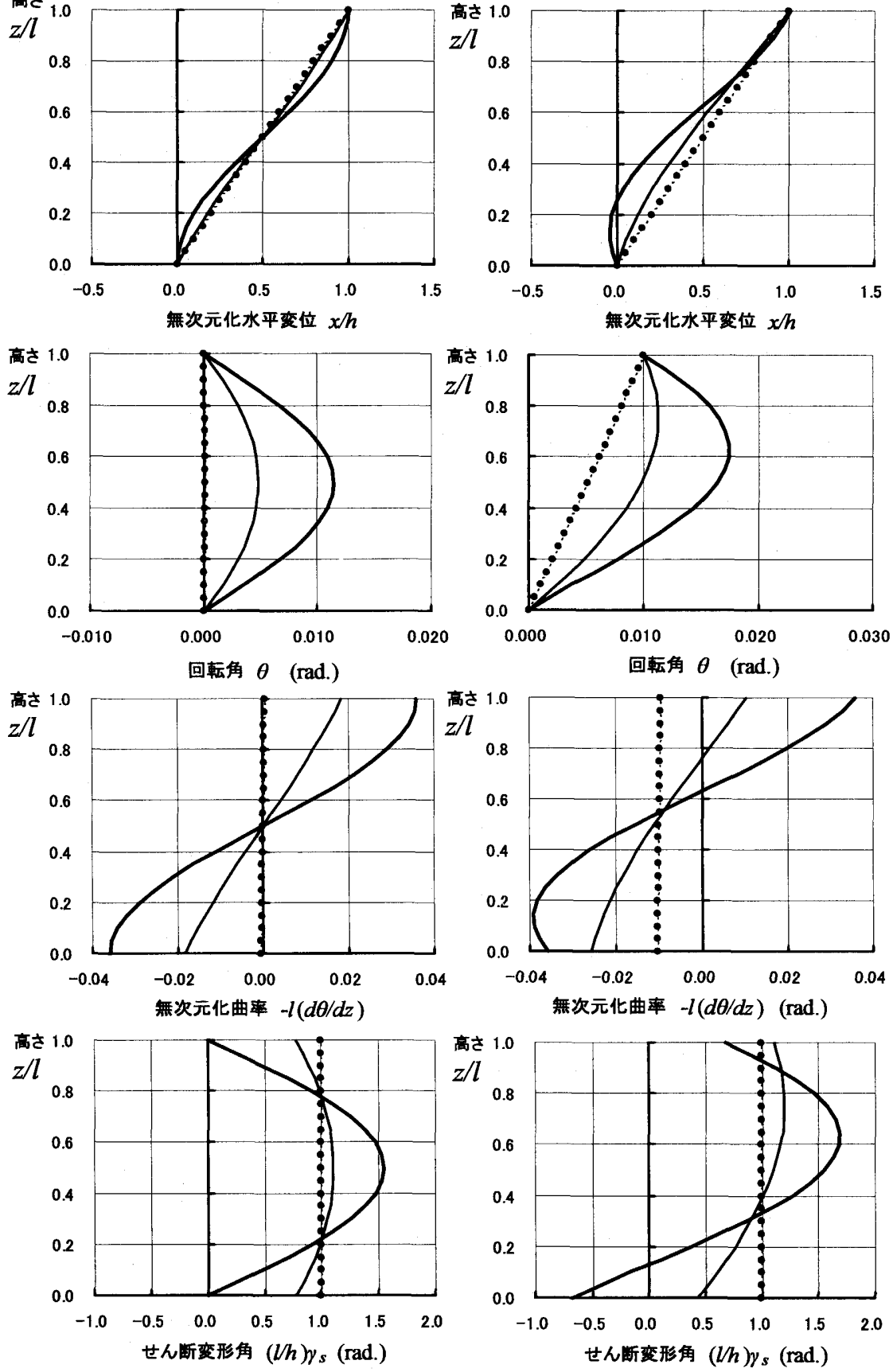

(a) 一端固定他端回転無し

$\left(\delta_{A}=h, \delta_{B}=0, \theta_{A}=\theta_{B}=0\right)$

(b) 一端固定他端回転有り

$\left(\delta_{A}=h, \delta_{B}=0, \theta_{A}=1 / 100, \theta_{B}=0\right)$

図 3 高さ方向変形分布における端部回転の有無による比較 
$\left(\delta_{A}=h, \delta_{B}=0, \theta_{A}=\theta_{B}=0\right)$

- 一端固定他端回転有り

$\left(\delta_{A}=h, \delta_{B}=0, \theta_{A}=1 / 100, \theta_{B}=0\right)$

鉛直荷重 $P / P_{c r}=0,0.5,1.0$ について、 無次元化水平変位 $x / h$, 回転角 $\theta$, 無次元化 曲率 $-l(d \theta / d z)$ お よびせん断変形角 $(l / h) \gamma_{s}$ の高さ方向分布を図 3 に示す。図よ り以下のことがわかる。

1) $P / P_{c r}=0$ のケースは、特性が軸力に無 関係なせん断要素に対応するもので、こ の場合には三角形分布あるいは一様分 布の変形分布を示す。ところが、鉿直荷 重がある場合は、この分布から大きくか け離れ、鉛直荷重が変形分布に甚大な影 響を及ぼしていることが明瞭である。

2）曲率の分布形状は水平変位分布に類似 している。これは P- $\Delta$ 効果による曲げ モーメントが支配的であることを意味 している。また、せん断变形角の分布形 状は回転角分布に類似している。これは $\mathrm{P}$ ー曰効果によるものである。

3）回転有りの $P / P_{c r}=1$ のケースでは、下部で水平変位が大きく外 側にはらみ出し、特に下端固定端直上部では全体変位とは逆向き の変位が生じている。座屈荷重付近になるとこのような特異な変 形が現れる特街がある。回転無しの場合でも、同様の兆候が見ら れ、事実もう少し大きな鉛直荷重を作用させると、上下端近傍で 外側にはらみ出す変形モードが目だってくる。変形分布が上下非 対称な場合では対称の場合に比べて、この外側へのはらみ出しが 著しいことがわかる。

4）回転有りの $P / P_{c r}=0.5$ のケースでは、その曲率分布から反曲点 が上端側にかなり寄っており、上下端の曲率すなわち固定端モ一

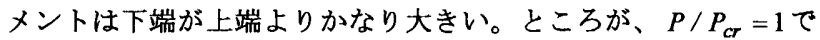
は、下側に偏った曲率分布を保持してはいるが、固定端モーメン トは上下端で同じ值である。なお、さらに大きな鉛直荷重を作用 させると、逆に上端の曲げモーメントが下端より大きくなる逆転 現象が現れる。

\section{3 近似剛性式の精度}

剛性マトリクスの構成要素である $k_{1}, k_{2}, k_{3}, k_{4}$ の 4 要素について、 厳密式(17)式と近似式 (30) 式を比較する。近似式における座屈荷重の 評価式として、理論式である(25) 式のほかに、(33)式も検討する。 $k_{1}$ を $S_{s} / l$ で、 $k_{2}$ を $P_{c r}$ で、 $k_{3}, k_{4}$ を $S_{b} / l$ でそれぞれ無次元化して、 $P / P_{c r}$ に対してプロットし、図 4 に示す。なお、 $k_{2}$ および横軸の $P$ の無次元化には厳密式(24)式の $P_{c r}$ を用いた。図より、以下のことが わかる。

1）いずれの要素においても、近似式(30)式は、簃密式(17)式と良く 一致している。

2）座屈荷重に理論式である(25) 式を用いて評価した近似式は、

（33）式を用いて評価した近似式より厳密式との一致度が良い。特 に $0.5 P_{c r}$ 以上の領域で (33) 式を用いて評価した近似式は精度低

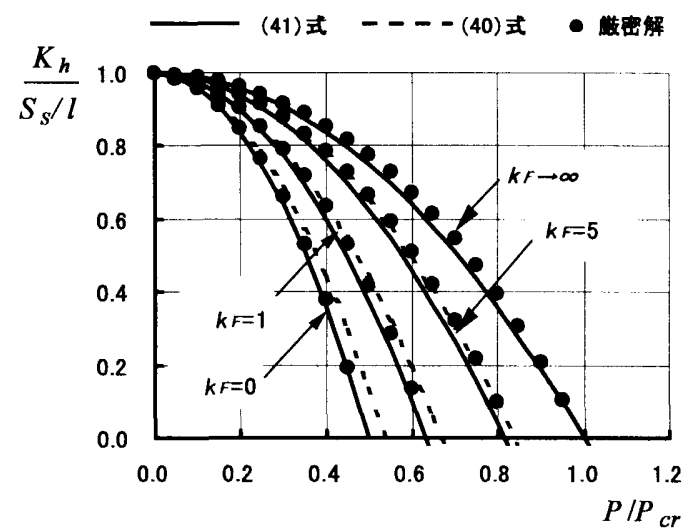

图 5 連結部材の回転拘束を考覻した 積層ゴムの水平剛性一鉛直荷重関係

下が比較的大きい。

\section{4 連結部材の回転剛性を考虑した積層ゴムの水平剛性式の精度}

$k_{F}=10^{6}, 5 ， 1 ， 0$ の 4 ケースについて、無次元化した水平剛性一 鉛直荷重関係を(40), (41) 式と Haringx 理論による厳密解で比較して 図 5 に示す。Haringx 理論による厳密解は、（31）式の代わりに (16)，(17) 式を用いて、（39）式を求めた手順に従って計算したもので ある。なお、横軸のP の無次元化には蕨密式 (24) 式の $P_{c r}$ を用いた。 図を細かく見れば、（40)式は $k_{F}=0$ の鉛直荷重が大きい領域で水平 剛性, 座屈荷重を過大評価し、一方、(41) 式は $k_{F}=0$ で厳密解と良 く一致しているが、 $k_{F}=5$ では水平剛性, 座屈荷重を若干過小評価 している。しかし、いずれの式も $\boldsymbol{k}_{F}$ の広範な範囲に対して厳密解と の誤差はわずかであり、実用上十分な精度の解が得られることがわか る。 


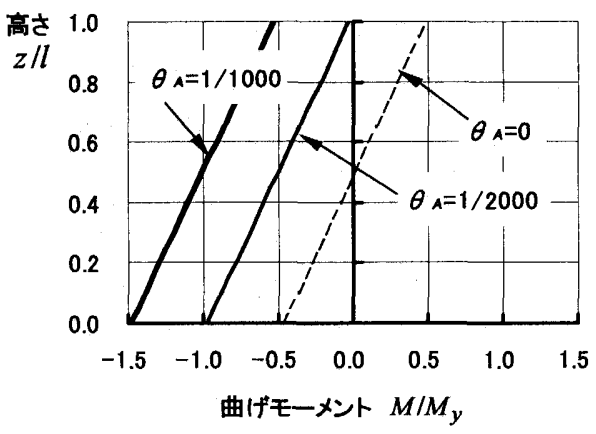

(a) $P / P_{c r}=0$

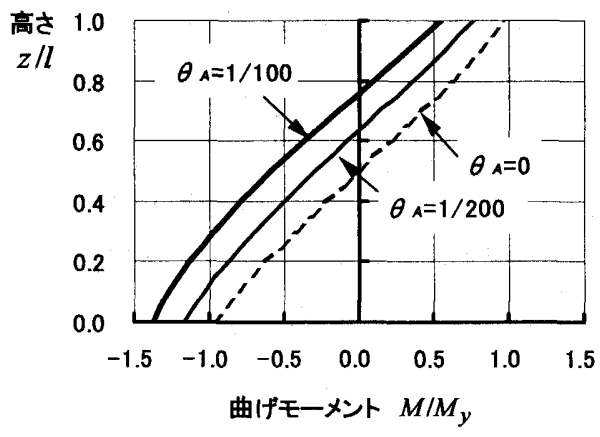

(b) $P / P_{c r}=0.5$

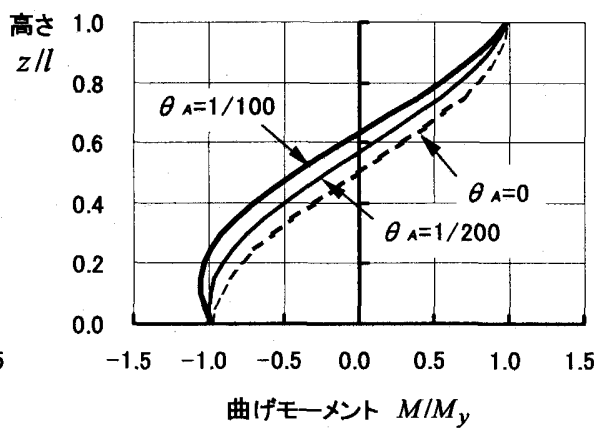

(c) $P / P_{c r}=1$

図 6 高さ方向の曲げモーメント分布（Haringx 理論の適用可能範囲 : $\left.|M| / M_{y} \leqq 1\right)$ [端部変位 $\left.\left(\delta_{A}-\delta_{B}\right) / h=1, \theta_{B}=0\right]$

\section{5 理論の適用可能な洨形限界}

ここでは、(43)式の条件から定まる変形限界に関して検討する。鉛 直荷重を $P / P_{c r}=0,0.5,1$ の 3 レベルに対して、端部変位として、 $\left(\delta_{A}-\delta_{B}\right) / h=1, \theta_{B}=0$ を固定して、 $\theta_{A}$ だけを 3 水準変えて $M(z) / M_{y}$ を計算した。 $\theta_{A}$ の值は、 $P / P_{c r}=0$ の場合 $\theta_{A}=0,1 / 2000$, $1 / 1000 、 P / P_{c r}=0.5$ および 1 の場合 $\theta_{A}=0,1 / 200,1 / 100$ とした。 $M(z) / M_{y}$ の高さ方向分布を図 6 に示す。

いずれの計算ケースにおいても、下端曲げモーメントが最大、ある いはほほ最大となっている。 $P / P_{c r}=0.5,1$ の場合、 $\theta_{A}=0$ では $\left|M_{A}\right| / M_{y}=\left|M_{B}\right| / M_{y} \approx 1$ とちょうど線形限界に達している。計算条件 である水平変形は $\delta_{A}-\delta_{B}=h$ で、これは直径の $1 / 4$ に対応している。 従って、計算結果は、(45)式の正当性を裹付けるものである。端部回 転がある場合には、 $P / P_{c r}=1$ の場合、 $\theta_{A}=1 / 100$ でもほぼ全長にわ たって $|M| / M_{y} \leq 1$ となっているのに対し、 $P / P_{c r}=0.5$ の場合、 $\theta_{A}=1 / 200$ で下端付近で $|M| / M_{y} \geq 1$ となっており、 $\theta_{A}=1 / 100$ では $|M| / M_{y} \geq 1$ の領域が上方に拡大している。 $P / P_{c r}=0$ の場合、 $\theta_{A}=1 / 1000$ でも下半分の領域が $|M| / M_{y} \geq 1$ となっている。

以上の結果は以下のようにまとめることができる。すなわち、曲げ 特性が線形範囲内にあるための両端間相対水平変位の限界值は、逆対 称曲げでは概ね直径の $1 / 4$ である。両端間相対回転角が存在する場合 では、その大きさに応じて限界值は低下し、特に鉛直荷重が小さいほ ど著しい。

\section{6. 結論}

端部回転を受ける積層ゴムの力学特性を Haringx 理論に基づいて 検討した。積層ゴム両端の水平自由度と回転自由度を考虑して剛性方 程式を定式化した。この剛性方程式は複雑であるため、理解の促進と 実用性の観点から剛性方程式の近似式を提示した。近似式の有効性と 利用法の一例を示すために、連結部材で端部回転が拘束された積層ゴ ムの水平剛性式を近似式を用いて導いた。また、積層ゴムのせん断特 性, 曲げ特性の線形限界条件を規定して、本論で提示した理論が適用 可能な材端水平変位, 材端回転角の限界值について考察した。最後に、 高さ方向の変位分布・断面力分布における特徽、剛性方程式の近似式 および連結部材で端部回転が拘束された積層ゴムの水平剛性式の精 度、理論が適用可能な材端変位の限界について、事例によって検討し た。これらの結果から、以下のことを確認した。

1）材端回転自由度を考慮した剛性方程式によって、力学挙動に及ほ
す端部回転の影響を理論的に評価することが可能になった。

2）鉛直荷重と端部回転が積層ゴムの高さ方向の変位分布・断面力分 布に大きな影響を与えることを示した。

3）剛性方程式の近似式は、積層ゴムの力学挙動に及ぼす鉛直荷重や 端部回転角の影響を簡潔に表現している。また、剛性方程式の近 似式は、実用上十分な精度を有している。

4）剛性方程式の近似式を用いることにより、連結部材の回転拘束を 考慮した積層ゴムの水平剛性式を容易に得ることができた。得ら れた式は、既往式と整合しており、厳密解との一致度も良い。

5）曲げ特性が線形範囲内にあるための両端間相対水平变位の限界 值は、逆対称曲げでは概ね直径の $1 / 4$ である。両端間相対回転角 が存在する場合では、その大きさに応じて限界値は低下し、特に 鉛直荷重が小さいほど著しい。

なお、上記 4)に関して、ここでは連結部材による回転拘束をひとつ の回転ばねで代表した単純なモデルで検討したが、より複雑なモデル を想定した場合、近似式がよりいっそう有効になるものと期待される。 端部回転を拘束した積層ゴムの圧縮せん断試験から、積層ゴムの力 学挙動は Haringx 理論で概ね説明できることが示されている吅えは13)。 一方で、高面圧下での非線形現象 (逆 S 字形履歴ループや硬化現象) ${ }^{13)}$ 、

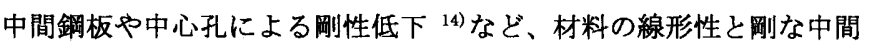
銅板を仮定した Haringx 理論では説明できない現象も確認されてい る。三山 ${ }^{7)}$ 梳、一部修正を施した Haringx 理論で、端部回転を与えた 積層ゴムの压縮せん断試験結果を説明した。しかし、これが端部回転 を与えた実験と Haringx 理論を比較した唯一の例であり、実験データ があまりにも少ない。本論で提示した理論式，近似式を用いる際、こ れらの点に十分留意する必要がある。また、端部回転を考虑した Haringx 理論の妥当性と適用範囲を実験的に検証することが今後の課 題である。

\section{多考文献}

1) Haringx, J. A : On highly compressible helical springs and rubber rods, and their application for vibration-free mountings, Philips Research Reports 3, pp. 401-449, 1948, Philips Research Reports 4, pp. 49-80, pp. 206-220, 1949

2) Gent, A. N. : Elastic stability of rubber compression springs, Journal Mechanical Engineering Science, Vol.6, No. 4, pp. 318-326, 1964

3) Thomas, A.G : The design of laminated bearings I, Proceedings of the Conference on NR for Earthquake Protection of Buildings, pp. 229-246, 1982

4) 藤田险, 藤田隆史 : 重量機器免唇用積層コムの静的加力実験 一第 3 報 剛 
性についての理論的検討一, 生産研究, 第 38 巻 4 号, pp. 189-191，1986. 4 5) 日本建築学会, 免震構造設計指針第 3 版, pp. 395-404, 2001 6) 饭塚真巨 : 積層ゴムの剛性マトリクス, 日本建築学会大会学術講演梗概集, 構造 B 巻, pp. 619-620, 1995

7) 三山用史 : 積層ゴムの上下面に回転角を与えた場合の力学性状に関する研究, 日本建築学会構造系論文集，第 556 号，pp. 43-50，2002.6

8) Buckle, I. G. and Kelly, J.M : Properties of slender elastomeric isolation bearings during shake table studies of a large-scale model bridge deck, Proc. Second Forld Congress on Joints and Bearings, American Concrete Institute, SP94-15, Detroit, pp. 247-269, 1986

9) Imbimbo, M and Kelly, J. M: Stability aspects of elastomeric isolators, Earthquake Spectra, Vol. 13, No. 3, pp. 431-449, 1997

10)飯塚真巨: 圧縮軸力・水平力同時作用下に拄ける免震用積層ゴムの大变形、 クロモデル，日本建築学会学術講演梗概集，椪造 B 巻，pp. 721-722，1992

11)飯塚真巨：積層ゴムの大変形挙動をシミュレートする巨視的力学モデル, 日 本建築学会構造系論文集, 第 568 号, pp. 83-90, 2003.6

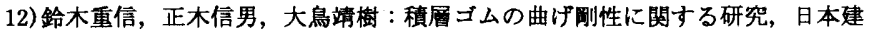
築学会学術譜演梗概集, 構造 B 巻, 1998, pp. 539-540

13) 飯塚真巨 : 低减衰皘層コムの力学特性評価式の適用性, 日本建筑学会楼造系 論文集，第 572 号，pp. 81-88，2003.10

14)例えば、二村有則ほか：積層コムの力学的特性に及ほす中間鋼板厚と中心れ 径の影響，第 10 回日本地震工学シンポジウム, pp. 2675-2680, 1998

付録 $k_{h}$ およひ $k_{r}$ の近似式の誘得

一端固定他端水平移動自由回転拘束の境界条件下での水平剛性 $k_{h}$ の厳密式(本文 (18) 式、以下本文は略す) から近似式(26) 式一の誘導、 および対象曲げにおける回転剛性の箃密式(19)式から近似式 (27) 式 一の誘導を行う。

$<k_{h}$ の近似式の誘導 $>$

$\tan (q l / 2)$ をその級数展開の第二項までを考慮し、下式で近似する。

$$
\tan \frac{q l}{2}=\frac{q l}{2}+\frac{1}{3}\left(\frac{q l}{2}\right)^{3}
$$

上式および(11)式を(18)式に代入して、下式となる。

$$
k_{h}=\frac{1}{\frac{l}{S_{s}}+\frac{l^{3}}{12 S_{b}}\left(1+\frac{P}{S_{s}}\right)^{2}}
$$

上式を Maclaulin 展開して $P^{3}$ 以上の項を無視し、(23) 式の条件 $\left(\left(S_{b} / l^{2}\right) / S_{s} \gg 1\right)$ を適用し、さらに（25）式を代入すると下式と なる。

$$
k_{h}=\left[1-\frac{\pi^{2}}{6} \frac{S_{s}}{P_{c r}} \frac{P}{P_{c r}}-\frac{\pi^{2}}{12}\left(\frac{P}{P_{c r}}\right)^{2}\right] \frac{S_{s}}{l}
$$

上式に(23) 式の条件 $\left(S_{s} / P_{c r} \ll 1\right)$ を適用すると、下式となる。

$$
k_{h}=\left[1-\frac{\pi^{2}}{12}\left(\frac{P}{P_{c r}}\right)^{2}\right] \frac{S_{s}}{l}
$$

上式において、 $P=P_{c r}$ で $k_{h}=0$ となるように、 $\pi^{2} / 12 \approx 1$ とみなせ ば、上式は下式となる。

$$
k_{h}=\left[1-\left(\frac{P}{P_{c r}}\right)^{2}\right] \frac{S_{s}}{l}
$$

上式はすなわち(26)式である。

$<k_{r}$ の近似式の誘導 $>$

$(q l / 2) / \tan (q l / 2)$ をその級数展開の第二項までを考慮し、(19)式を 下式で近似する。

$$
k_{r}=\frac{q l / 2}{\tan (q l / 2)} \frac{S_{b}}{l}=\left[1-\frac{1}{3}\left(\frac{q l}{2}\right)^{2}\right] \frac{S_{b}}{l}
$$

（11）式および(25)式を上式に代入して、下式となる。

$$
k_{r}=\left[1-\frac{\pi^{2}}{12}\left\{\frac{S_{s}}{P_{c r}} \frac{P}{P_{c r}}+\left(\frac{P}{P_{c r}}\right)^{2}\right\}\right] \frac{S_{b}}{l}
$$

上式に(23)式の条件（ $S_{s} / P_{c r} \ll 1 ）$ を適用すると、下式となる。

$$
k_{r}=\left[1-\frac{\pi^{2}}{12}\left(\frac{P}{P_{c r}}\right)^{2}\right] \frac{S_{b}}{l}
$$

上式において、 $P=P_{c r}$ で $k_{r}=0$ となるように、 $\pi^{2} / 12 \approx 1$ とみなせば、 上式は下式となる。

$$
k_{r}=\left[1-\left(\frac{P}{P_{c r}}\right)^{2}\right] \frac{S_{b}}{l}
$$

上式はすなわち(27)式である。

(2006年 3 月 6 日原稿受理， 2006 年 7 月 6 日採用決定） 